\title{
The Rufous-throated Dipper Cinclus schulzi on rivers in north-west Argentina and southern Bolivia
}

\author{
STEPHANIE J. TYLER and L. TYLER
}

\begin{abstract}
Summary
Surveys of river birds were made in north-west Argentina in October 1993 and in southern Bolivia in December 1994. Data were collected on foraging behaviour, breeding biology and breeding abundances of the Rufous-throated Dipper Cinclus schulzi (a threatened species) on three river systems in Tucumán and Jujuy provinces in Argentina and on two river systems in Tarija department in Bolivia. Rufous-throated Dippers foraged from wetted rocks and when standing in water in riffles and on the edges of cascades and waterfalls; swimming or diving was not observed. Five nests were found in Argentina, two of which were incomplete. One had a clutch of two eggs and another contained two well-grown, feathered nestlings; the fifth was inaccessible. These records indicate that breeding starts early in the Argentinian spring. Nests of adjacent pairs of Rufous-throated Dippers were from c.650-1,200 $\mathrm{m}$ apart. Juvenile plumage resembles that of the adult. Some information is provided on the biometrics of seven birds caught in mist-nets, and on vocalizations and on the relative abundance of dippers, Torrent Ducks Merganetta armata and two species of Cinclodes. Possible threats to rivers within the range of the Rufous-throated Dipper include reservoir construction, hydroelectric and irrigation schemes, eutrophication, deforestation and stock-grazing. Pollution, reduced flows and river channel modification are more prevalent at lower altitudes below the breeding range of the Rufous-throated Dipper.
\end{abstract}

\section{Introduction}

The Rufous-throated Dipper Cinclus schulzi is the rarest of the five species of dipper (family Cinclidae) which occur from the Americas (three species: American C. mexicanus, White-capped C. leucocephalus and Rufous-throated) to Europe and North Africa and across to Asia (White-throated $C$. cinclus), where the fifth species (Brown C. pallasii) overlaps with C. cinclus. The Rufous-throated Dipper has a very restricted range in southern Bolivia and north-west Argentina. Because of its small range and its potential vulnerability to modern developments such as reservoirs, hydroelectric and irrigation schemes, as well as to perceived threats of deforestation and cattle encroachment, it was included by Collar et al. (1992) in the Red Data Book of American birds. The little that was known of its population size or of its general ecology, from the work of 
ornithologists such as the late C. C. Olrog, and Manuel Nores and R. Vides Almonacid, was summarized by Niels Krabbe in Collar et al. (1992).

We spent three weeks in Argentina in the known range of the species in October 1993 to investigate various aspects of its ecology and breeding biology. We also spent three weeks in Tarija department in southern Bolivia in December 1994 to gather more data and to gain some understanding of the distribution of Rufous-throated Dippers. A Rufous-throated Dipper had been observed on the Río Victoria close to Tarija in 1993 by Anna McGrane (pers. comm.), some 50 to $60 \mathrm{~km}$ west of its previous known range. A brief summary of our observations in Argentina has already been published (Tyler 1994) but some other preliminary data, mainly on feeding behaviour and on the abundance of the Rufous-throated Dipper in relation to two aquatic furnariids Cinclodes spp., are presented here as well as data on the distribution of the Rufous-throated Dipper in Bolivia. Some Rufous-throated Dipper nests and their contents, and juvenile plumage, are described. Comparisons are made between the ecology of the Rufous-throated Dipper and other species of dipper, notably the White-throated Dipper C. C. gularis, which has been the subject of long-term studies in Wales (Tyler and Ormerod 1994a). Attention is drawn to some of the probable threats to the Rufous-throated Dipper in north-west Argentina and southern Bolivia. It should be stressed that these findings are based on very limited fieldwork and that therefore we can only speculate on factors affecting distribution and on the importance of various threats.

\section{Study area and methods}

From 10 to 30 October we travelled in Jujuy, Salta and Tucumán provinces in north-west Argentina, visiting as many accessible rivers as possible within the Andean alder Alnus acuminata zone between c.1,500 and 2,500 $\mathrm{m}$, where the Rufous-throated Dipper is known to breed (Fjeldså and Krabbe 1990). We also visited some streams and rivers at both lower and higher altitudes outside this zone. Most time was spent in the Sierra de Aconquija south-west of Tucumán. At a sample of sites we surveyed varying lengths of watercourses, recording all river birds that we saw and various physiographic features such as stream width, bankside cover and gradient/flow (e.g. rapid flow with numerous riffles, cascades and waterfalls; moderate flow with extensive rock/stone shoals).

For two weeks in December 1994, when in Tarija department in southern Bolivia, we visited as many tributaries of the Río Guidalquivir and Río Camacho (which join to form the Rio Tarija) as possible on the eastern side of the mountain ridge running north to south close to the town of Tarija. We walked up each river to which we were able to gain access, often for $2-3 \mathrm{~km}$ along braided sections in wide unstable rocky beds where there were water-worn rounded boulders and pebble shoals, until we reached stretches which were physiographically suitable for dippers. We then attempted to walk $1-2 \mathrm{~km}$ of these stretches. We also briefly visited the area close to Narvaez near Entre Ríos in Tarija department, where Rufous-throated Dippers were first reported in Bolivia (Remsen and Traylor 1983) and south of which Mayer (1993) observed the species in 1992 in the Reserva Nacional de Flora y Fauna Tariquia. 
Any nests found on either visit were photographed and details recorded of the nest sites, their height above water and, where accessible, their contents. Some observations were made of adults at nests.

The location of each river bird in the river corridor was noted, i.e. in mid-river, marginal (within $1 \mathrm{~m}$ of the bank) or riparian zone (up to $20 \mathrm{~m}$ from the river) and whether on rocks, shoals, grass or other vegetation. Opportunistic data were obtained on foraging techniques, viz. flycatching, diving, picking prey from vegetation, shoals or rocks when walking or wading, and on prey.

Mist-nets were used to catch a sample of Rufous-throated Dippers; all birds caught were weighed (to $0.5 \mathrm{~g}$ ) by spring balance, and the length of their wings (maximum flattened chord), tarsi (using the method described by Schmid and Spitznagel 1985) and bills (tip to feathering) were measured to $0.5 \mathrm{~mm}$.

\section{Results}

\section{Distribution and abundance of river birds}

Argentina Only 15 Rufous-throated Dippers were encountered; these were on rivers of the Los Sosa system in the Aconquija in Tucumán province and on the Yala River near Termas de Reyes, north of Jujuy (Table 1), all in well-forested areas. On "good" stretches, pairs had adjacent territories of 500-1,000 $\mathrm{m}$ in length, but there were long sections of river in the alder zone where dippers were absent. These differed in character from occupied stretches, the latter having numerous cascades and waterfalls, mid-river rocks and rocky cliffs or banks adjacent to the water. Unoccupied stretches often had unstable channels with exposed and dry areas of water-worn rocks along their edges; others were characterized by low flows and by much accumulated sediment on the river bed or had a general paucity of good cascades and waterfalls. Rivers where dippers were found were 5-15 $\mathrm{m}$ in width, although two pairs had nests, and sometimes foraged, on much smaller streams close to their confluences with larger rivers.

Some narrow, partly tree-lined streams within the alder zone were devoid of Rufous-throated Dippers. Cinclodes species were, however, present on these as well as on many other watercourses, both on very narrow streams ( $1 \mathrm{~m}$ wide) or much broader rivers, outside the alder zone. Generally the sections with dippers had few if any cinclodes. Bar-winged Cinclodes C. fuscus ( 54 birds) were much more numerous overall than White-winged Cinclodes $C$, atacamensis (15) on surveyed stretches. Both species occurred at altitudes from $1,000 \mathrm{~m}$ to over $3,000 \mathrm{~m}$. Three individuals of each of these two species were also recorded on broad river channels below 1,500 $\mathrm{m}$ a.s.l., where the gradients were lower and where the residual flows in $100-300 \mathrm{~m}$ wide channels meandered close to rock banks. The highest abundances of Cinclodes, however, were noted on the upper $3 \mathrm{~km}$ of the Río Sosa downriver of the reservoir near Tafi del Valle, at below 2,500 $\mathrm{m}$ a.s.1., where 16 Bar-winged and six White-winged Cinclodes were counted. This was a rather open section with many exposed rocks and shoals and with well-grazed pasture alongside the river. The uppermost kilometre had a gentler gradient than the rest of the stretch. 


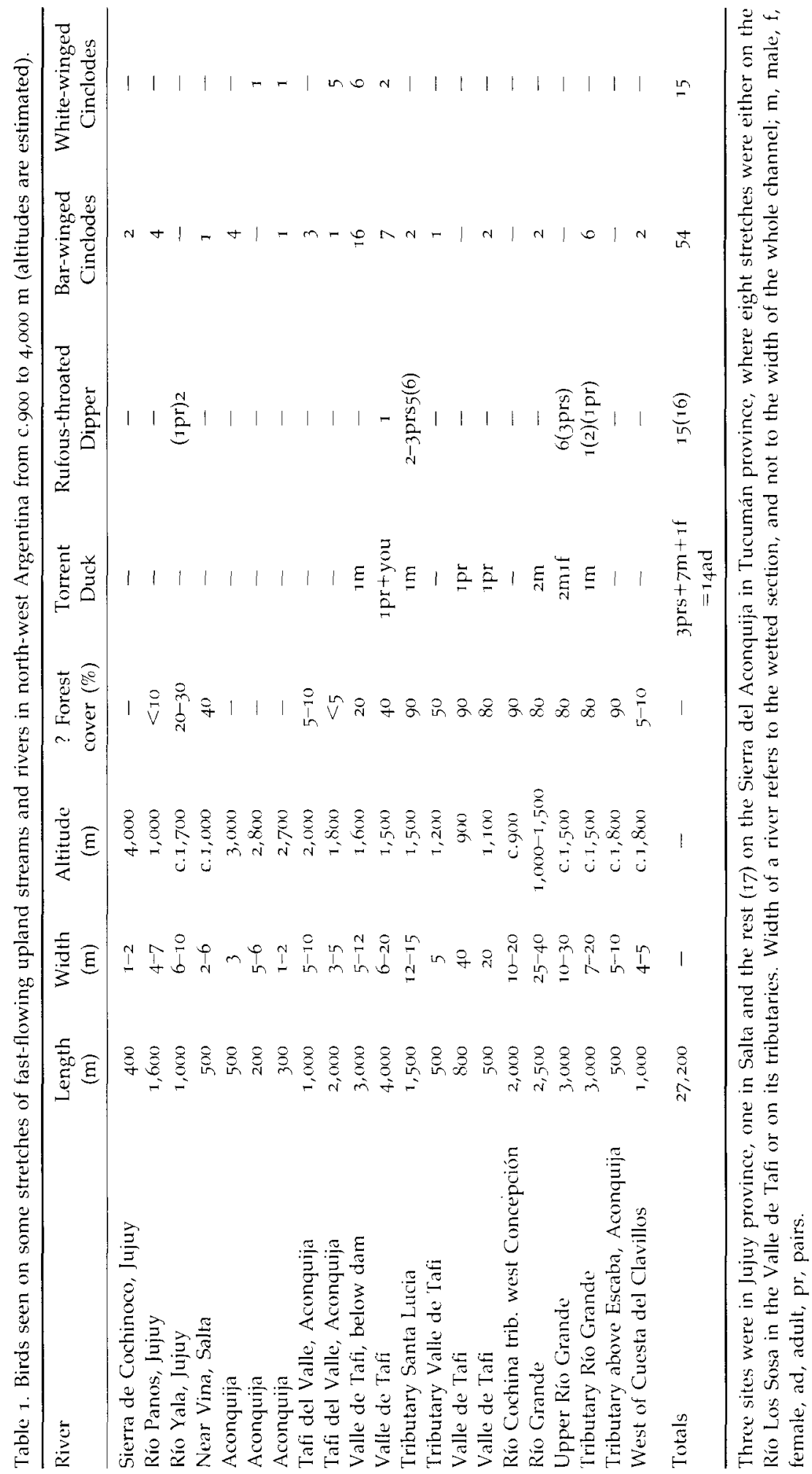


The virtual absence of dippers from $7 \mathrm{~km}$ of the upper section of the main river in the Valle de Tafi was notable. Much of this section appeared physiographically suitable although the water was full of filamentous green algae and any exposed rocks were covered with carpets of drying algae. By contrast Bar-winged Cinclodes and White-winged Cinclodes were, as noted above, particularly numerous there. Limited surveys and spot checks of the river lower down the valley revealed no Rufous-throated Dippers and only occasional cinclodes.

Bolivia We found nine or ten Rufous-throated Dippers on the Río Tarija (Guidalquivir) system. Birds were seen on tributaries of the Río Calama to the north-west of Tomatas near Tarija, on the Río Erquis and Río Coimata, which together with the Río Victoria join the Guidalquivir at Tomatas, and as far south as Río la Huerta near Camacho, at altitudes of 2,000 to 2,500 m. Rufous-throated Dippers were seen on every physiographically suitable stretch of river that we visited, suggesting that they occur on the upper reaches of any permanent river flowing east from the "western" ridge. Dipper stretches were in steep-sided valleys or in gorges, where there were cliffs, huge boulders and numerous waterfalls, and where the river was only $10-15 \mathrm{~m}$ in width. Rufous-throated Dippers occurred alongside Torrent Ducks Merganetta armata and White-winged Cinclodes. We saw very few Bar-winged Cinclodes on the "dipper" rivers, although we observed them more frequently at higher altitudes in Tarija Department (and on many rivers further north in Bolivia). During surveys of c. $18 \mathrm{~km}$ of river (of which only $8 \mathrm{~km}$ were suitable for dippers) between 1,500 and 2,500 $\mathrm{m}$, we counted six Rufous-throated Dippers, 12 White-winged Cinclodes, no Bar-winged Cinclodes and four Torrent Ducks.

These western Bolivian rivers were soft-water rivers with rather impoverished invertebrate faunas dominated by stonefly nymphs (Plecoptera). Pairs of Rufous-throated Dippers appeared to have rather long territories of $1-2 \mathrm{~km}$. Although there were a few scattered alders along the river banks, the valley sides were covered with grasses and often xerophytic shrubs, and occasional remnant patches of Polylepis woodland, a very different habitat from the rich humid forested rivers where we located C. schulzi in Argentina and also from the better known Bolivian Rufous-throated Dipper rivers near and south of Narvaez, to the east of the "eastern" ridge. Rivers in this latter area were much richer in invertebrates than those to the west, containing abundant mayflies (Ephemeroptera) and caddisfly larvae (Trichoptera), which are important prey for dippers elsewhere. We surveyed only one apparently suitable river to the north of Narvaez (c. $5 \mathrm{~km}$ north) but found no dippers. The northern extent of the species's range remains to be determined; a month-long visit to this area is planned for November to December 1995.

\section{Foraging and diet of Rufous-throated Dippers and cinclodes}

Dippers were generally shy, but in Argentina one pair on the Rio Grande and another on the Yala allowed more prolonged observations. Over 500 foraging attempts were noted, during which the birds foraged in two rather similar ways. They either perched on rocks in the river, then moved down to the water's 
edge, leaning down to pick prey from the surface of the rock at or below the water surface, or they waded in shallows or stood on the lips of cascades and waterfalls, and picked items from the surface of the rocks below the water. In this last situation the birds sometimes had to flap their wings to maintain their balance in the rapid current. They also often had their heads below water, with water splashing over their backs. At no time did we observe Rufous-throated Dippers swimming or diving for food in the manner of White-throated, North American or Brown Dippers.

The aquatic invertebrates that were visible on rocks in the feeding areas favoured by Rufous-throated Dippers included small mayfly nymphs (Ephemeroptera) and both cased caddis and web-spinning caddis (Trichoptera). At many sites freshwater molluscs were also present.

Between feeding bouts in any one location, dippers hopped up onto rocks and either preened or indulged in wing-flicking, at each flick showing a brief white flash as the white inner webs of both the primary and secondary feathers were exposed.

Often the sky was overcast and it was misty or raining during our brief study period. In such weather birds were active throughout the day, but when it was hot and sunny birds were difficult to find. At these times both the dippers and the cinclodes frequently "shaded", perching under rock overhangs or in rock crevices. Regular shelters (and possible night-time roost sites) were evident from the many faeces on the rocks.

Both Cinclodes species foraged from rocks in the river, picking items from the rocks either above or below the water surface. They also both waded in shallow water, up to the tops of their tarsi, taking prey from the river bed, but most commonly they fed from marginal shoals and muddy edges. Here both species, but particularly the larger White-winged Cinclodes, used their bills to turn over leaves, sticks, debris and stones, and probe for or peck at prey. Bar-winged Cinclodes on the Los Sosa in the Valle de Tafi frequently probed into the algal mats on the rocks and pecked small insects from this vegetation; chironomid and simuliid larvae (Diptera) were evident here. They also spent some time foraging on grassland a short distance away from the river.

Over half $(55 \%, n=104)$ of the observations of locations of Bar-winged Cinclodes in the river corridor were of birds on rocks, mainly marginal ones. However, this apparent preference was because, when disturbed, birds flew or hopped up onto rocks to obtain a better view of the threat or to hide; they did not spend much time foraging from these compared with foraging on shoals ( $24 \%$ of locations) or in riparian vegetation (14\%). Many other Bar-winged Cinclodes were seen away from streams in pastures and around villages.

\section{Breeding biology of the Rufous-throated Dipper}

Five nests were found in Argentina, all in the Aconquija (details below). Two of these were still being constructed; another had eggs; one contained young and the fifth was inaccessible. At a further site the behaviour of the presumed male suggested there were small nestlings at a site in a steep, narrow tributary, but the nest was not located. The sequence of nest-building and the shape and construction of the nest dome from mosses, of the cup from grasses and the 
Table 2. Comparison of wing and tarsus and weight (means) of adult Cinclus schulzi in Argentina (see Table 3), C. pallasii in Nepal (Tyler and Ormerod 1994a) and two races of C. cinclus: C. c. gularis in Wales (Ormerod it al. 1986, Ormerod and Tyler 1990), and C. C. minor, a large race in Morocco (Tyler and Ormerod 1991).

\begin{tabular}{|c|c|c|c|c|c|c|}
\hline Cinclus schulzi & \multicolumn{2}{|c|}{$\begin{array}{l}\text { Mean wing } \\
\text { length }(\mathrm{mm})\end{array}$} & \multicolumn{2}{|c|}{$\begin{array}{l}\text { Mean tarsus } \\
\text { length (mm) }\end{array}$} & \multicolumn{2}{|c|}{$\begin{array}{l}\text { Mean } \\
\text { weight }(g)\end{array}$} \\
\hline & & & & & & \\
\hline All & 81.5 & (7) & 32.3 & (7) & 39.5 & (7) \\
\hline $\mathrm{M}$ & 82.9 & (5) & 32.5 & (5) & 40.8 & (5) \\
\hline $\mathrm{F}$ & 78.0 & (2) & 31.75 & (2) & 36.55 & (2) \\
\hline \multicolumn{7}{|l|}{ C. pallasii } \\
\hline All & 97.5 & (5) & 36.2 & (5) & 73.2 & (5) \\
\hline \multicolumn{7}{|l|}{ C. C. gularis } \\
\hline $\mathrm{M}$ & 96.7 & (182) & 34.6 & (201) & 69.7 & (259) \\
\hline F & 88.3 & $(270)$ & 32.6 & $(236)$ & 57.3 & (259) \\
\hline \multicolumn{7}{|l|}{ C. c. minor } \\
\hline $\mathrm{M}$ & 102.8 & (9) & 36.1 & (9) & 76 & (9) \\
\hline $\mathrm{F}$ & 94.3 & (3) & 34.9 & (3) & 68.1 & (3) \\
\hline
\end{tabular}

Samples sizes are given in parentheses.

lining from leaves, were very similar to those of the White-fronted Dipper. Although Rufous-throated Dippers are considerably smaller than White-throated Dippers (Table 2), their nests were almost the same size.

In Bolivia we noted only three nests on tributaries of the Río Tarija, all on damp rock faces at the river's edge. One was empty, presumed used prior to our visit. One had two eggs and the third was a new nest, but had no nest lining and an incomplete entrance hole.

Nest 1 On 16 October a complete nest was found near Santa Lucia on a tributary of the Río Los Sosa in the Valle de Tafi below Angostura Dam, at c.2,000 $\mathrm{m}$ altitude. Unfortunately this was sited in a crevice on a overhanging rock at the edge of the river, c. $3 \mathrm{~m}$ above a deep pool below a waterfall, and was consequently not accessible. The male was singing from a rock near the nest. No female emerged from the nest when it was lightly touched with a stick, suggesting that it was either empty or egg-laying had only just commenced.

Nest 2 On 18 October a part-built nest was found on the same tributary as nest $I$ and about $800 \mathrm{~m}$ from this nest, on the supporting wall of an old bridge about $50 \mathrm{~m}$ upriver of the confluence with the main river. The circular base of the bottom, sides and top of the dome had been built. Five days later the nest was only a little further advanced.

Nest 3 On 20 October a complete nest with one white egg, about half the size of an egg of a White-throated Dipper, was located on the Río Grande, west of Cap. Caceres between Concepción and Monteros, at c.1,500 m. This was only $0.5 \mathrm{~m}$ above a pool, on an overhanging rock face. The female was flushed from the nest in the late morning. Two days later the female was incubating a clutch of two eggs. 
Nest 4 This was found about 1,200 $\mathrm{m}$ upriver from nest 3. It was sited on a wetted rock face at the edge of a small waterfall in a narrow gorge on a side stream about $20 \mathrm{~m}$ from its confluence with the Rio Grande. There was a light "whitewash" of faeces below the nest which contained two well-grown nestlings. Their flight-feathers were over half-emerged from the feather sheaths and their bodies completely feathered. The plumage was identical to that of the adults, i.e. grey with a rufous throat-patch, and with white webs to the emerged parts of the flight-feathers, although still with wispy down feathers on the head and nape. They were the equivalent age of a 17-19-day-old White-throated Dipper nestling, but unlike the latter did not attempt to leap out of the nest when they were replaced. Two days later they were still in the nest, being fed by both adults. At most visits to the nest, the adults appeared to carry few and small prey in their bills compared to the large conspicuous loads carried by White-throated Dippers; at most visits each adult removed a faecal sac and flew away from the nest with it. The large young called as the adults approached the nest. The adults collected food both on the tiny side stream, which was rich in caddis larvae and mayfly nymphs, and on the main river.

Weights of the young on 20 October were near adult weights (see Biometrics section below).

Nest 5 This was being actively built on 22 October some $2.5 \mathrm{~m}$ above the river level in a breccia (boulders in mudstone) bank, and was at a similar stage to nest 2 on 23 October. It was sited just $665 \mathrm{~m}$ upriver from nest 4 . At midday only one bird, presumed to be the female, was carrying mosses to the nest, cautiously approaching it and then sitting in it adding the nest material carefully to the developing dome. The second bird accompanied the first but then sat on a rock in mid-river, frequently singing, whilst its mate continued nest-building.

\section{Biometrics of Rufous-throated Dippers}

Seven Rufous-throated Dippers were caught in mist-nets in Argentina. Their mean wing-length was $81.5 \mathrm{~mm}$ and mean weight $39.5 \mathrm{~g}$ (Tables 2 and 3). All were lighter and had shorter wings than the smallest female White-fronted Dippers, but their tarsi were proportionately longer (Table 2).

Two definite pairs were trapped The other three birds from their behaviour were all thought to be males (at one site the female was incubating when her

Table 3. Biometrics of seven Rufous-throated Dippers caught in north-west Argentina in October 1993 and one in Bolivia in December 1994.

\begin{tabular}{lcllll}
\hline Site & Sex & Wing & Bill & Tarsus & Weight \\
\hline Río Yala, Jujuy & $\mathrm{M}$ & 82 & 13 & 33 & 40.5 \\
Río Los Sosa & $\mathrm{M}$ & 82 & 12 & 33 & 39.8 \\
Valle de Tafi, Aconquija & $\mathrm{F}$ & 77 & 12 & 31 & 35.9 \\
Valle de Tafi, Aconquija & $\mathrm{M}$ & 82 & 13 & 30.5 & 40.6 \\
Río Grande, Aconquija & $\mathrm{M}$ & 85 & 11.5 & 32 & 40.8 \\
Río Grande, Aconquija & $\mathrm{M}$ & 83.5 & 13 & 34 & 41.7 \\
Río Grande, Aconquija & $\mathrm{F}$ & 79 & 12 & 32.5 & 37.2 \\
Río La Huerta & $\mathrm{M}$ & 86 & 13 & 33 & - \\
\hline
\end{tabular}

Wing (maximum chord), bill from tip to feathering and tarsus (see text) were measured to $\pm 0.5 \mathrm{~mm}$ and weight to $\pm 0.1 \mathrm{~g}$. 
mate was caught). The two females, identified by their brood-patches, were smaller than the males (Tables 2 and 3 ), suggesting that there is sexual dimorphism in size, albeit slight, as there is in White-throated Dippers (e.g. Ormerod et al. 1986, Tyler and Ormerod 1991) and Brown Dippers (Ali and Ripley 1983).

The two dipper nestlings from nest 4 weighed $37 \mathrm{~g}$ and $37.9 \mathrm{~g}$ on 20 October. Their tarsi were also well developed, measuring 35 and $35.2 \mathrm{~mm}$, longer than any of the adults' tarsi.

One bird, a probable male, was caught in Bolivia (Table 3) and was similar in size to the Argentinian birds.

\section{Voice}

Fjeldså and Krabbe (1990) stated that there were no data on calls or song for the Rufous-throated Dipper, although Castelino (1985) noted that the alarm call was a metallic keek-keek. The loud, shrill alarm calls that we heard given by the adults at nest 4 , by other birds when disturbed and by birds extracted from mist-nets were barely distinguishable from those given by White-throated Dippers in similar situations (and by other species of dipper).

We heard song on several occasions. One bird, presumed to be a male, sang from a rock below a waterfall close to the completed nest 1 . Another sang from a rock in mid-river whilst its mate took moss to a part-built nest (nest 5). Whilst reminiscent of that of a White-throated Dipper, the song sounded more thrush-like.

Calls of nestlings in nest 4 were remarkably similar to those of nestlings of other dipper species that we have heard.

\section{Discussion}

\section{Foraging behaviour and distribution}

Rufous-throated Dippers are largely confined to the Bosques district of the Yungas zone, a narrow strip of forest, much of it dominated by alder, between 1,200 and $2,500 \mathrm{~m}$, which runs southwards, somewhat intermittently, from Tarija department in Bolivia down through Salta, Jujuy and Tucumán into northern Catamarca in Argentina (Nores 1987).

It seemed from our admittedly brief visit that even within the Yungas zone, where Andean alders dominate the upper forests, suitable rivers for Rufousthroated Dippers were rather limited. The nature of the mountains within the forested zone results in a drainage pattern dominated by a main river, subject to spates, in each steep-sided valley, and a plethora of very steep narrow tributaries, many of which are dry for part of the year. There are relatively few wide permanent tributaries. On the main rivers only the upper section has a relatively stable channel with the large rocks, waterfalls, rapids and riffles apparently required by the Rufous-throated Dipper in the breeding season. Inevitably therefore the populations of these dippers may be somewhat limited. On suitable sections, however, as on that part of the upper Río Grande that we surveyed, birds may be locally common, but well separated from those on other rivers. It would be interesting to conduct a ringing programme on different river systems to look at dispersal patterns and movements of juveniles to other 
watersheds. It is known that Rufous-throated Dippers undertake altitudinal winter movements, moving down as low as $800 \mathrm{~m}$ (M. Nores in Collar et al. 1992) but nonetheless it would be useful to determine whether there is any interchange between, for example, the Aconquija population and that to the north of Jujuy or in the Baritu National Park or across the Bolivian border into Tarija Department.

The true extent of the Bolivian population of C. schulzi remains unknown, but in the light of the species's widespread occurrence on permanent streams near Tarija and it being locally common south of Narvaez (Mayer 1993), the population is unlikely to be less than 1,000 pairs.

Our limited observations of the foraging behaviour of the Rufous-throated Dipper confirm those of M. Nores (Collar et al. 1992), indicating that this species of dipper rarely, if ever, dives for prey. However, Castelino's (1985) reports that it is sometimes submerged are correct insofar as when birds were feeding on the lips of small waterfalls, facing upstream, they were often effectively underwater each time they dipped their heads below the surface to peck for food. Their feet, however, continued to grip the substratum, even in the strongest currents. The proportionately long tarsi of the Rufous-throated Dipper compared with White-throated or Brown Dippers (Table 2) indicates that their legs may be used more in feeding than those of these last species. The White-capped Dipper also feeds in a similar manner to the Rufous-throated Dipper, and has not been recorded diving (Fjeldså and Krabbe 1990, S. Lasso in litt.). We speculate that possibly the coexistence of Rufous-throated (and White-capped) Dippers with Torrent Ducks on Andean rivers has led to the difference in foraging behaviour between the South American dippers and species of dipper elsewhere. Torrent Ducks occupy the "diving for invertebrate prey" niche and the South American dippers have developed other strategies. The foraging behaviour of Rufousthroated Dippers is very similar to that of Little Forktails Enicurus scouleri on Himalayan rivers where the large Brown Dipper spends much time diving for prey (Tyler and Ormerod 1994b). More data would be useful throughout the year to show if foraging behaviour of the Rufous-throated Dipper ever changes, for example when river flows are very high.

Salvador et al. (1986) suggested that competition between the Rufous-throated Dipper and aquatic furnariids may play some role in causing the restricted range and abundance of the former, although Collar et al. (1992) thought this was doubtful. Dippers and the Cinclodes spp. use the river corridor and forage in rather different ways. Although in Argentina Bar-winged and White-winged Cinclodes occurred on watercourses used by dippers, they were as or more numerous on narrow often treeless streams and open rocky rivers both within and outside the altitudinal range in which the dipper breeds. Many of the streams on which the cinclodes occurred offered few feeding opportunities for dippers, having rather low gradients and/or restricted flows, much sediment and few cascades and waterfalls. Other rivers, or sections of rivers, used by the more opportunistic cinclodes were largely dry, had unstable beds and often had extensive exposed shoals and rocks. There were some apparently suitable rivers, however, where Rufous-throated Dippers were absent; rivers of a similar char- 
acter in Britain would have supported the more opportunistic White-throated Dipper. Whether the more specialized behaviour of Rufous-throated Dippers evolved because of possible competition with Torrent Ducks and cinclodes species is debatable, but competition with the furnariids, from our limited observations, seems unlikely. The cinclodes foraged along shoals and in the marginal and riparian zone, pecking for prey in a manner similar to Grey Wagtails Motacilla cinerea and their probing and flicking over of vegetation was more akin to behaviour shown by Slaty-backed E. schistaceus, Black-backed E. immaculatus and Spotted Forktails E. maculatus in the Himalaya, with the larger White-winged Cinclodes turning over stones as does the large Spotted Forktail (Tyler and Ormerod 1994b). As both Grey Wagtails and forktails occur alongside Whitethroated and Brown Dippers on numerous Himalayan rivers, it can be argued that cinclodes and Rufous-throated Dippers are similarly able to coexist without competition.

\section{Breeding biology}

Salvador et al. (1986) first described the nest and eggs of the Rufous-throated Dipper, although Fraga and Narosky (1985) refer to eight nests previously found on rock faces by $\mathrm{C}$. C. Olrog about $\mathrm{I} \mathrm{m}$ above the water, and they found a half-built nest on 2 January 1982 . The descriptions of the nest and eggs, found by Salvador et al. (1986) in the Valle de Tafi, differ little from our own observations although the grassy inner cups of our nests 3 and 4 were lined with leaves rather than with plastic and paper found by Salvador et al. This was no doubt due to the nests on the Río Grande being in a more remote situation away from any roads or tracks. The part-built nest (nest 2) that we found in the Valle de Tafi was surrounded by human litter.

Of three nests found by Salvador et al. (1986), one had a single egg on 21 December which was found cold and deserted three days later. Another was empty on 21 December but contained two eggs on 24 December. The third nest was empty on both these dates. Collar et al. (1992) refer to three nests found by $M$. Nores in September 1988 but there is no indication of whether these were occupied. Collar et al. also noted that B. M. Whitney observed copulation in early January 1988.

These limited previous observations suggested that the main breeding season was December/January (although M. Nores's notes show that a wider spread must exist) and that the clutch was perhaps two eggs. Back calculations from our data show that some pairs of Rufous-throated Dippers start nest-building or repairing old nests in early September, possibly in August, at the end of the dry season. For example, if it is assumed that incubation and fledging lengths are similar in Rufous- and White-throated Dippers (i.e. 16 days and c.22 days), the female at nest 4 must have started laying in mid-September and the two young hatched in the first day or two of October. The female at nest 3 started laying on 20 October and the complete clutch was apparently two eggs. More data are clearly needed to show whether clutch-size is consistently of two eggs, and to show the full extent of the breeding season and when the peak in egglaying occurs. 


\section{Threats}

M. Nores, in Collar et al. (1992), believed that most streams within the Rufousthroated Dipper's range were in an acceptable state. In a letter to $W$. Belton on 5 July 1985, Nores reported that he had found dippers just below La Cienaga, the reservoir below the town of Tafi del Valle, and suggested that this indicated that the species was not very sensitive to contamination. R. Vides Almonacid (in Collar et al. 1992) did, however, suggest that rivers in the Rufous-throated Dipper's range were in serious long-term danger from modification through hydrological change, deforestation and stock-rearing.

We did not see much evidence of a continuing serious large-scale deforestation problem in the Aconquija or in Jujuy province, despite the fact that the rivers that we studied are those which had easier access, although there was widespread cutting of trees for firewood and construction, and some burning of vegetation. Grazing by stock, mainly by cattle and horses but sheep and goats too, occurred throughout that part of the forest zone that we visited. In the past extensive areas alongside some sections of the rivers have been cleared of trees for ranching; these are still largely clear of trees or shrubs, and stock tracks linking these open grasslands permeate through wooded areas and across the rivers. We do not feel that the present level of grazing by cattle and horses is a major problem for Rufous-throated Dippers as there is still good tree growth and regeneration of alders in the areas we visited. Bankside trees do not seem to be imperative for the dippers as on the Rio Yala dippers were on sections where trees were set well back from the watercourse, and on the Río Grande the birds were on a river in a gorge where trees were again well away from the actual river corridor. The western Rufous-throated Dipper rivers in the Tarija department of Bolivia have already largely lost forest cover in their catchments, although there are some forest remnants, scrub and riverside alders. If grazing were seriously to affect bankside cover and hence to reduce the input of organic material into the rivers and to accelerate erosion and sedimentation, this would be detrimental to aquatic invertebrates and hence riparian birds (e.g. Kaufmann and Krueger 1984). The Torrent Duck has also disappeared from some Andean rivers owing to siltation following deforestation (Fjeldså and Krabbe 1990), but there are few data from Argentina about its historical or current status.

Of immediate concern is the construction of dams and reservoirs, associated holiday resorts, hydroelectric schemes and trout-rearing stations on the rivers. The enrichment of the Los Sosa river below the reservoir in the Valle de Tafi in the Aconquija was evident, from the abundant algal growth, for most of the river's length down to below $900 \mathrm{~m}$, and may have made feeding difficult for the dippers or eliminated favoured and available prey. Possibly the situation has declined since $M$. Nores recorded dippers there in 1985, given that they were virtually absent on the main river in 1993. Their presence on the contrastingly clean tributary near Santa Lucia further indicates that enrichment is probably the key factor. Holiday houses are still being constructed in the area and effluent from these developments is a possible cause of the problem. Although the observed eutrophication of the Los Sosa may be the main reason that dippers were so scarce on this river, releases of water from the reservoir may be an additional factor. Such releases may scour the river channel, moving 
stones and rocks, and making the river less stable, so reducing invertebrate prey.

There is a reservoir, holiday village and hydro-scheme at Escaba on the Río Singuil, the southernmost river in the Aconquija range, and a hydro-scheme, dam and fish-rearing tanks on the Río Grande, above and below which the river is considerably modified; one section of $\mathrm{c} .200 \mathrm{~m}$ was completely dry and, lower down, periodic (once a day or every two days during our visit) sudden releases of water further modified the river and its aquatic life. We found no dippers on these affected stretches, nor at Termas de Reyes near Jujuy where there is a hydro-scheme, but other observers, e.g. Castelino (1985), have noted birds here.

Fjeldså and Krabbe (1990) suggested that the Torrent Duck may have declined in the Andes due to food competition from introduced trout. A similar concern has been expressed by some authors (e.g. Kear and Burton 1971) about the endemic Blue Duck Hymenolaimus malacorhynchus of New Zealand, which feeds on invertebrates such as caddis larvae in mountain rivers. However, the Río Grande and one tributary, part of which we surveyed, were well-stocked with trout, but dippers and Torrent Ducks were still present on physiographically suitable stretches.

Fortunately most of the upper reaches of the forested rivers within the Rufous-throated Dipper's range are still relatively unmodified by man and largely inaccessible, except on foot. However, the restricted number of suitable rivers and the narrow strip of suitable habitat in the Yungas zone (Nores 1987) means that the dipper population must be small, and therefore any adverse impact on these rivers must be considered a threat to the species.

At lower altitudes where some Rufous-throated Dippers winter (Collar et al. 1992), there are many other threats to rivers. Irrigation schemes, mainly for tobacco and sugarcane, result in many rivers being dry or almost so by the end of the winter (the dry season). The widespread gravel and stone extraction from the river shoals and canalization of some sections must locally have a detrimental impact on some breeding birds as well as on invertebrates, fish and other biota. On some rivers in the eastern foothills there was severe pollution from molasses from sugarcane factories, as well as from human effluent and refuse.

\section{Acknowledgements}

We thank staff from BirdLife International, notably Nigel Collar, Martin Kelsey and Niels Krabbe, and Mike Moser from the International Waterfowl Research Bureau for much helpful advice. We also thank an anonymous referee for his helpful comments on a first draft of this paper, and Jim and Anna McGrane for their hospitality and support in Bolivia.

\section{References}

Ali, S. and Ripley, S. D. (1983) A pictorial guide to the birds of the Indian Subcontinent. Delhi: Oxford University Press.

Castelino, M. A. (1985) Mirlo de Agua en Jujuy. Nuestras Aves 3: 26. 
Collar, N. J., Gonzaga, L. P., Krabbe, N., Madroño Nieto, A., Naranjo, L. G., Parker, T. A. and Wege, D. C. (1992) Threatened birds of the Americas: the ICBP/IUCN Red Data Book. Cambridge, U.K.: International Council for Bird Preservation.

Fjeldså, J. and Krabbe, N. (1990) Birds of the high Andes. Copenhagen: [Copenhagen and] Svendborg Zoological Museum, University of Copenhagen and Apollo Books.

Fraga, R. and Narosky, S. (1985) Nidificación de las aves argentinas (Formicariidae a Cinclidae). Buenos Aires: Asociación Ornitológica del Plata.

Kaufmann, J. B. and Krueger, W. C. (1984) Livestock impacts on riparian ecosystems and streamside management implications: a review. J. Range Management 37: 430-437.

Kear, J. and Burton, P. J. K. (1971) The food and feeding apparatus of the Blue Duck Hymenolaimus. Ibis 113: 483-493.

Mayer, S. (1993) Birds observed in and near the reserve of Tariquia, dpto. Tarija, Bolivia, in September/October 1992. Unpublished report.

Nores, M. (1987) Zonas ornitogeográficos de Argentina. Pp.295-305 in T. Narosky and D. Yzurieta (English Edition 1989) Birds of Argentina and Uruguay. Buenos Aires: Asociación Ornitológica del Plata (Vásquez Mazzini Editores).

Ormerod, S. J. and Tyler, S. J. (1990) Assessments of body condition in dippers Cinclus cinclus: potential pitfalls in the derivation and use of condition indices based on body proportions. Ringing and Migration 1x: 31-41.

Ormerod, S. J., Tyler, S. J. and Lewis, J. M. S. (1986) Biometrics, growth and sex ratios amongst Welsh Dippers Cinclus cinclus. Ringing and Migration 7: 61-70.

Remsen, J. V. and Traylor, M. A. (1983) Additions to the avifauna of Bolivia, part 2. Condor 85: 95-98.

Salvador, S., Narosky, S. and Fraga, R. (1986) First description of the nest and eggs of the Rufous-throated Dipper (Cinclus schulzi) in north-western Argentina. Gerfaut 76 : 63-66.

Schmid, W. and Spitznagel, S. (1985) The sexual size dimorphism of south-German dippers (Cinclus c. aquaticus): biometrics, function and possible causes. Ökologie der Vögel 7: 379-408. (In German with English summary.)

Tyler, S. J. (1994) The Yungas of Argentina: in search of Rufous-throated Dipper Cinclus schulzi. Cotinga 2: 38-40.

Tyler, S. J. and Ormerod, S. J. (1991) Aspects of the biology of dippers Cinclus cinclus minor in the Atlas Mountains of Morocco outside the breeding season. Bonn. Zool. Beitr. 42: $35-45$.

Tyler, S. and Ormerod, S. (1994a) The dippers. London: T. \& A. D. Poyser.

Tyler, S. J. and Ormerod, S. J. (1994b) The ecology of river birds in Nepal: some implications of land use changes. Forktail 9: 59-82.

STEPHANIE J. TYLER and L.TYLER

Yew Tree Cottage, Lone Lane, Penallt, Gwent NP5 4AJ, U.K. 